\title{
Erratum to: Phyto-molecular profiling and assessment of antioxidant activity within micropropagated plants of Dendrobium thyrsiflorum: a threatened, medicinal orchid
}

\author{
Paromik Bhattacharyya $^{1} \cdot$ Suman Kumaria ${ }^{1} \cdot$ Nikhil Job $^{1} \cdot$ Pramod Tandon $^{1}$
}

Published online: 8 July 2015

(C) Springer Science+Business Media Dordrecht 2015

\section{Erratum to: Plant Cell Tiss Organ Cult DOI 10.1007/s11240-015-0783-6}

The articles by Teixeira da Silva (2014) and Teixeira da Silva et al. (2015) were incorrectly listed in the References section in the original publication. They are correctly listed below.

\section{References}

Teixeira da Silva JA (2014) The phloroglucinol conundrum: increase in root growth of hybrid Cymbidium (Orchidaceae) with no toxic effect on protocorm-like body formation. Plant Tissue Cult Biotechnol 23:275-282

Teixeira da Silva JA, Cardoso JC, Dobránszki J, Zeng S (2015) Dendrobium micropropagation: a review. Plant Cell Rep 34:671-704

The online version of the original article can be found under doi:10.1007/s11240-015-0783-6.

Suman Kumaria

sumankhatrikumaria@gmail.com

1 Plant Biotechnology Laboratory, Department of Botany,

Centre for Advanced Studies, North-Eastern Hill University,

Shillong 793022, Meghalaya, India 